\title{
Corrosion of AISI 316 Stainless Steel Embedded in Green Concrete with Low Volume of Sugar Cane Bagasse Ash and Silica Fume exposed in Seawater
}

\author{
Miguel Angel Baltazar-Zamora, Laura Landa-Ruiz, Aldo Emelio Landa-Gómez, \\ Griselda Santiago-Hurtado, Victor Moreno-Landeros, Ce Tochtli Méndez Ramírez, \\ Victor Fernandez Rosales, and René Croche
}

\begin{abstract}
In the present research the corrosion behavior of AISI 316 Stainless Steel was analyzed, as reinforcement in Green Concrete made with Low Volume of Sugar Cane Bagasse Ash (SCBA) and Silica Fume (SF), compared to AISI 1018 steel. Four concrete mixtures were made, all with a ratio $\mathrm{w} / \mathrm{c}=\mathbf{0 . 6 5}$, the percentages of substitution were $0 \%, 10 \%, 20 \%$ and $30 \%$. The specimens were exposed in seawater as an aggressive medium, corrosion was evaluated by monitoring the corrosion potential $E_{\text {corr }}$ (ASTM C-876-15) and corrosion rate $i_{\text {corr }}$ (ASTM G59). The results of $E_{\text {corr }}$ and $i_{\text {corr }}$ after 150 days of exposure show a better performance of AISI 316 steel, with a $10 \%$ of probability corrosion and a negligible level of corrosion respectively, the Green Concrete with $30 \%$ partial replacement of the CPC by the combination of SCBA-SF presented the best protection against corrosion.
\end{abstract}

Keywords - AISI 316, Corrosion, Green Concrete, SCBA, SF, Seawater.

\section{INTRODUCTION}

For a couple of decades, researchers have pointed out that the corrosion process is one of the main deteriorations of reinforced concrete, considering it as an affectation of the performance of structures [1]-[4]. The corrosion in concrete structures is a very important economic, by billions of dollars in the world [5]-[10] concentrating these repair costs mainly on the infrastructure built in marine environments [11]-[21], it is for the above that in recent years, the scientific community has worked to counteract this phenomenon with different perspectives, from innovation in concrete technology, as well as cement, special additions of inhibitors, among others, as well as studies of different media, marine, urban, both real and simulated [22]-[26]. One of the most aggressive means is where the structures are exposed in marine environments, where high concentrations of chlorides are present, and the phenomenon of corrosion is more accelerated [27]-[34] also the sulfate ions are also considered as aggressive agents [35]-[46]. To diminish this phenomenon, there is a history of the use of additions or substitutions of

Submitted on January 07, 2022.

Published on January 28, 2022.

Miguel Angel Baltazar-Zamora, Universidad Veracruzana, México.

(e-mail: mbaltazar@uv.mx)

Laura Landa-Ruiz, Universidad Veracruzana, México.

(e-mail: lalanda@uv.mx)

Aldo Emelio Landa-Gómez, Universidad Veracruzana, México.

(e-mail: aldlanda@ ${ }^{@ v . m x)}$

Griselda Santiago-Hurtado, Universidad Autónoma de Coahuila, México.

(e-mail: grey.shg@ gmail.com) portland cement for such as rice clay ash [47], fly ash [48], [49], sugar cane bagasse ash [50]-[52] and slag from blast furnace [53]. Likewise, the use of stainless steel 316 to reduce the phenomenon of corrosion and therefore increase the durability of concrete structures exposed in marine environments [54]. In this investigation, reinforced concrete specimens with sustainable concrete and reinforcement steels of 304 stainless steel and AISI 1018 steel were made. The ternary concretes were made with substitutions of sugarcane bagasse ash (SCBA) and silica fume (SF) agroindustry and industrial waste products respectively. Likewise, a conventional concrete was developed to be used as reference and comparison for ternary concrete. Results of $\mathrm{E}_{\text {corr }}$ and $\mathrm{I}_{\text {corr }}$ from the steels of a 180-day evaluation period are presented for the sustainable concrete exposed to a marine environment as an aggressive environment and drinking water as a means of control. The main objective of this research is to contribute to the scientific society with information necessary to build sustainable concrete structures that help increase the durability of these exposed in marine environments, and likewise, that present an environmental and economic benefit to our society.

\section{MATERIALS AND METHOdS}

\section{A. Materials}

1) Dosage of Concrete Mixtures

The dosage of concrete mixtures was carried out according to the method of ACI 211.1 [55].

\begin{tabular}{ccc} 
TABLE I: SUMMARY OF AGGREGATE & \multicolumn{3}{c}{ CHARACTERIZATION RESULTS } \\
\hline \hline $\begin{array}{c}\text { Physical properties of } \\
\text { materials }\end{array}$ & $\begin{array}{c}\text { Coarse } \\
\text { aggregate }\end{array}$ & $\begin{array}{c}\text { Fine } \\
\text { aggregate }\end{array}$ \\
\hline $\begin{array}{c}\text { Specific Mass (MES) g/cm } \\
\text { Bulk Volumetric Mass }\end{array}$ & 2.60 & 2.20 \\
(BVM) Kg / $\mathrm{cm}^{3}$ & 1332 & 1442 \\
Absorption (\%) & 1.7 & 1.8 \\
Module of Fineness & - & 2.94 \\
Maximum Size Nominal & $3 / 4 "$ & - \\
(TMN) &
\end{tabular}

Victor Moreno-Landeros, Universidad Autónoma de Coahuila, México. (e-mail: vmmorlan@ gmail.com)

Ce Tochtli Méndez, Universidad Veracruzana, México. (e-mail: cmendez uv.mx)

Victor Fernandez Rosales, Universidad Veracruzana, México.

(e-mail: vifernandez@uv.mx)

René Croche Belin, Universidad Veracruzana, México.

(e-mail: rcroche ${ }^{@}$ uv.mx) 
This method is based on the quality of the concrete required, taking into account mainly the resistance to strength compression ( $\left.\mathrm{F}^{\prime} \mathrm{c}\right)$, the settlement (workability or consistency), and in addition to the characterization of the physical properties of the aggregates (sand and gravel) to be used, knowing these parameters it is possible to perform the necessary concrete dosage, which determines the quantity of materials (cement, water, gravel and sand). Table I summarizes the physical characteristics of the aggregates, the tests were performed in accordance with the ASTM standards [56]-[59].

Table II summarizes the dosages of the Green Concretes produced. The study mixtures were with relation $\mathrm{w} / \mathrm{c}=0.65$. The reference mixture (REF) with $100 \%$ composite portland cement (CPC). Subsequent mixtures were made partial portland cement substitutions from $10 \%$ to $30 \%$, these percentages were formed by $50 \%$ of each addition used, for example, the second mixture with partial replacement of $10 \%$ CPC by SCBA and SF it contains is of 5\% Sugar Cane Bagasse Ash and 5\% of Silica Fume.

TABLE II: DOSAGE OF CONCRETE MIXTURES IN KG FOR $1 \mathrm{M}^{3}$

\begin{tabular}{|c|c|c|c|c|}
\hline Materials & REF & $\begin{array}{c}10 \% \\
(05 \mathrm{SCBA} 05 \mathrm{FS})\end{array}$ & $\begin{array}{c}20 \% \\
(10 \mathrm{SCBA} 10 \mathrm{FS})\end{array}$ & $\begin{array}{c}30 \% \\
(15 \mathrm{SCBA} 15 \mathrm{FS})\end{array}$ \\
\hline Water & 205.00 & 205.00 & 205.00 & 205.00 \\
\hline $\begin{array}{l}\text { Cement } \\
\text { Sugar }\end{array}$ & 315.00 & 283.5 & 252.00 & 220.50 \\
\hline $\begin{array}{c}\text { Cane } \\
\text { Bagasse } \\
\text { Ash }\end{array}$ & 0.00 & 15.75 & 31.50 & 47.25 \\
\hline $\begin{array}{l}\text { Silica } \\
\text { Fume }\end{array}$ & 0.00 & 15.75 & 31.50 & 47.25 \\
\hline $\begin{array}{c}\text { Fine } \\
\text { aggregate }\end{array}$ & 746 & 746 & 746 & 746 \\
\hline $\begin{array}{c}\text { Coarse } \\
\text { aggregate }\end{array}$ & 881 & 881 & 881 & 881 \\
\hline
\end{tabular}

\section{B. Method}

1) Characterization of Fresh and Hardened of Green Concrete

In accordance with the ONNCCE and ASTM standards [60]-[63], the tests were carried out to determine the physical and mechanical characteristics of the fresh and hardened concrete. The tests performed were slump, temperature, volumetric mass, and compressive strength $\left(\mathrm{F}^{\prime} \mathrm{c}\right)$, the results are summarized in Table III.

TABLE III: PROPERTIES OF GREEN CONCRETE (FRESH AND HARDENED STATE)

\begin{tabular}{ccccc}
\multicolumn{5}{c}{ (FRESH AND HARDENED STATE) } \\
\hline \hline TEST & REF & $\begin{array}{c}10 \% \\
\text { (05SCBA05FS) }\end{array}$ & $\begin{array}{c}20 \% \\
(\text { 10SCBA10FS) }\end{array}$ & $\begin{array}{c}30 \% \\
(15 S C B A 15 F S)\end{array}$ \\
\hline $\begin{array}{c}\text { Slump, cm } \\
\text { Temperature, } \\
{ }^{\circ} \mathrm{C}\end{array}$ & 8 & 7 & 6.5 & 6 \\
$\begin{array}{c}\text { Density, } \\
\mathrm{kg} / \mathrm{m}^{3}\end{array}$ & 25 & 24.5 & 24.0 & 23.5 \\
$\mathrm{~F}^{\prime} \mathrm{c}, \mathrm{Kg} / \mathrm{cm}^{2}$ & 337 & 2268 & 2273 & 2289 \\
\hline \hline
\end{tabular}

\section{2) Specifications of the test specimens}

The following steel bars were embedded in the study specimens: an AISI 1018 steel bar with a 3/8 "diameter, the second 316 stainless steel bar with a $3 / 8$ " diameter and a third 304 stainless steel bar with a diameter of $1 / 16$ ". The first two bars were used as working electrodes (WE) for the evaluation of the corrosion behavior (monitoring of $\mathrm{E}_{\text {corr }}$ and $\mathrm{I}_{\text {corr }}$ ) as indicated in the literature [64], the two bars delimit an area of exposure as shown in Fig. 1. A 304 stainless steel rod was used as the auxiliary electrode.

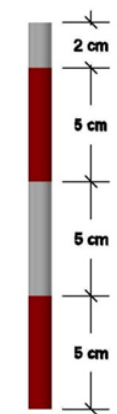

Fig. 1. Characteristics of bars embedded in Green Concrete.

\section{3) Nomenclature of the specimens}

For the identification of laboratory tests and steels for electrochemical evaluation, the nomenclature presented in Table IV is established. It is mainly based on the Green Concrete mixtures, the exposure medium and the steels embedded in the concrete.

TABLE IV: NOMENCLATURE TEST SPECIMENS OF GREEN CONCRETE $\begin{array}{llll}\text { REF } & 10 \% & 20 \% & 30 \%\end{array}$

\begin{tabular}{|c|c|c|}
\hline$\%$ & (05SCBA05FS) & (10SCBA10FS) \\
\hline
\end{tabular}

REF-1-8 05SCBA05FS-1-8 10SCBA10FS-1-8 15SCBA15FS-1-8

REF-1-6 05SCBA05FS-1-6 10SCBA10FS-1-6 15SCBA15FS-1-6

REF-2-8 05SCBA05FS-2-8 10SCBA10FS-2-8 15SCBA15FS-2-8

REF-2-6 05SCBA05FS-2-6 10SCBA10FS-2-6 15 SCBA15FS-2-6

- $\mathrm{REF}=$ Concrete $(100 \% \mathrm{CPC})$

- 05 SCBA05FS = Concrete with $10 \%$ of SCBA-SF

- $10 \mathrm{SCBA} 10 \mathrm{FS}=$ Concrete with $20 \%$ of SCBA-SF

- $15 \mathrm{SCBA} 15 \mathrm{FS}=$ Concrete with $30 \%$ of SCBA-SF

- 1 = Water (Control environment).

- 2 = Seawater (Aggressive environment).

- 6 = AISI 316 Stainless Steel.

- 8 = AISI 1018 Carbon Steel.

4) Specimens exposed to seawater (Electrochemical cell).

For the evaluation of the electrochemical behaviour of the steels embedded in the Green Concrete, concrete cubes were made $(15 \times 15 \times 15 \mathrm{~cm})$. The electrochemical cell was manufactured in accordance with what is established in ASTM G59 [65] to be able to use linear polarization resistance electrochemical (LPR), see Fig. 2. Technology and the results were detected by the "Analysis" of version 4 of ACM. The parameters used to perform the LPR test, they were the same as those used by other researchers [66], the sweep potential was $\pm 20 \mathrm{mV}$ with respect to the corrosion potential and the sweep rate was $10 \mathrm{mV} / \mathrm{minute}$, the IR drop potential was considered. The corrosion current density $\left(\mathrm{I}_{\text {corr }}\right)$ was estimated from resistance to charge transference $(\mathrm{Rct})$ using:

Corrosion Current Density $\left(\mathrm{I}_{\text {corr }}\right)=\mathrm{B} / \mathrm{Rct}\left(\mu \mathrm{A} / \mathrm{cm}^{2}\right)$

where B is Stern-Geary constant $(\mathrm{B}=26 \mathrm{mV}$ for uniform corrosion) [67]. 
This monitoring was conducted weekly with the concrete cubes immersed in Water as Control environment and Seawater as Aggressive environment.

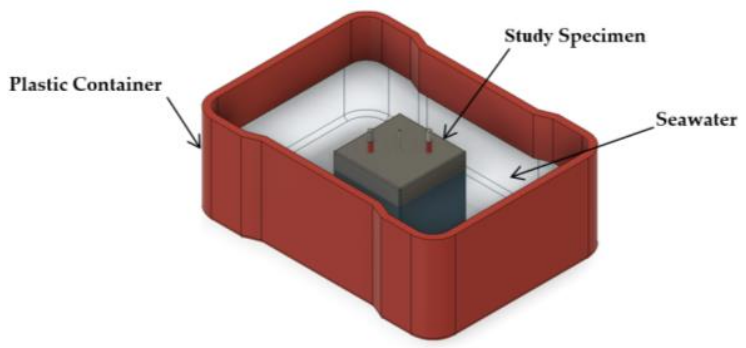

Fig. 2. Study specimens exposed to seawater.

\section{RESULTS AND DISCUSSION}

\section{A. Corrosion Potential $\left(E_{\text {corr }}\right)$}

Table V shows the values obtained according to the ASTM C876-15 [68], to interpret the results of the corrosion potential of each of the test specimens, adding a rank according to the literature [69].

\begin{tabular}{cc} 
TABLE V: CORROSION POTENTIAL IN REINFORCED CONCRETE $\left(\mathrm{E}_{\mathrm{CORR}}\right)$ \\
\hline \hline Corrosion potentials $\mathrm{mV}$ vs Cu/CuSO \\
\hline$<-500$ & Severe corrosion \\
$<-350$ & $90 \%$ Probability of Corrosion \\
-350 to -200 & Uncertainty \\
$>-200$ & $10 \%$ Probability of Corrosion \\
\hline \hline
\end{tabular}

In Fig. 3, we can observe the behavior of the corrosion potential of AISI 316 embedded in the Green Concretes exposed to a control environment $\left(\mathrm{H}_{2} \mathrm{O}\right)$, in the stage of curing the stainless steels present $\mathrm{E}_{\text {corr }}$ values in a range of -40 to $-180 \mathrm{mV}$. Then there is a trend with a decrease in $\mathrm{E}_{\text {corr }}$ values, which we can observe from day 28 to 63 . Subsequently, the $\mathrm{E}_{\text {corr }}$ values are maintained in an area of $10 \%$ probability of corrosion, and we can observe a better performance of the stainless steel embedded in the concrete with $20 \%$ and $30 \%$ substitution of CPC by the combinations SCBA and SF in low volume.

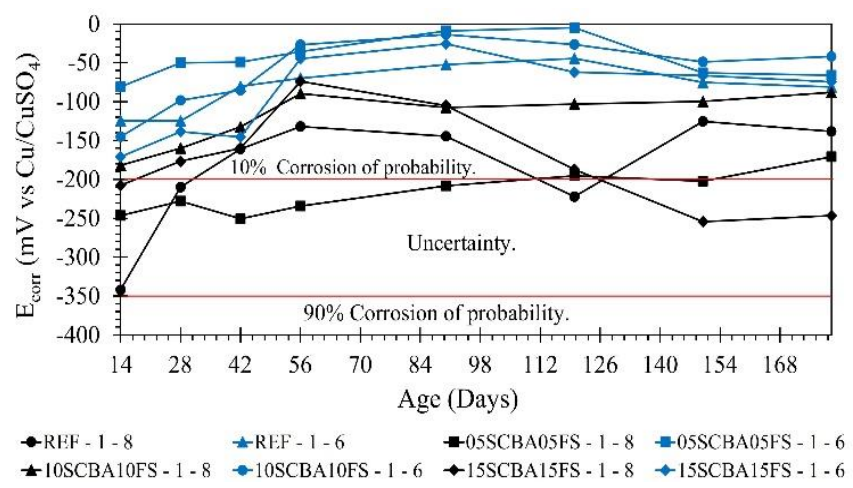

Fig. 3. $\mathrm{E}_{\text {corr }}$ of 316 and 1018 steel in concrete exposed to control environment.

The AISI 1018, have a greater variability in the corrosion potentials values $\left(E_{\text {corr }}\right)$, this showed more negative Ecorr values in the stage of curing (until 28 day), with $\mathrm{E}_{\text {corr }}$ values in a range of -190 to $-345 \mathrm{mV}$. The results after 28 days are in a range of $-105 \mathrm{mV}$ to $-230 \mathrm{mV}$, the mixture that presents a best behaviour with $\mathrm{E}_{\text {corr }}$ values located in the zone of $10 \%$ probability of corrosion, is the substitution of $20 \%$ of combination of SCBA and SF (10SCBA10FS-1-8).

Nevertheless, the mixtures with 10 and $30 \%$ of combination of SCBA and SF in the last days of monitoring, present Ecorr values that indicate indicating according to the ASTM C-876 standard corrosion uncertainty.

In Fig. 4, the behaviour of stainless steel 316 exposed to a seawater (Aggressive environment) is presented, a similarity of potentials in the reference mixture and with substitutions in the curing stage is observed. During the exposure time we can observe that the mixtures are maintained in an area of $10 \%$ probability of corrosion, the ranges are of the order of -160 $\mathrm{mV}$ and $-20 \mathrm{mV}$. The stainless steels that present a greater positive tendency are those that are found within the 15SCBA15FS and 10SCBA10FS mixtures.

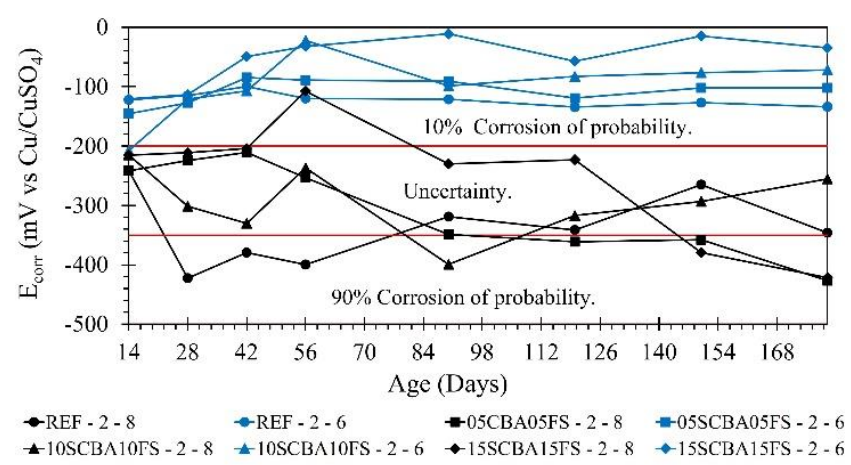

Fig. 4. $\mathrm{E}_{\text {corr }}$ of 316 and 1018 steel in concrete exposed to a marine environment.

In the case of AISI 1018, there is a trend of more negative $\mathrm{E}_{\text {corr }}$ results compared with AISI 316, the AISI 1018 embedded in 05SCBA05FS and REF-2-8 concretes present more negative $\mathrm{E}_{\text {corr }}$ values, in a range of $-240 \mathrm{mV}$ to $-430 \mathrm{mV}$. The opposite case of the 10SCBA10FS and 15SCBA15FS mixtures at the beginning of the evaluation presented more positive $\mathrm{E}_{\text {corr }}$ results and from day 63 they tended to an area of greater negativity to reach an area of $90 \%$ probability of corrosion.

A. Corrosion Current Density ( $\left.I_{\text {corr }}\right)$

TABLE VI: LEVEL OF CORROSION ACCORDING TO I CORR $_{\text {COR }}$

\begin{tabular}{cc}
\hline \hline Corrosion rate & Level of Corrosion \\
$\left(\mathrm{I}_{\text {corr }}\right) \mu \mathrm{A} / \mathrm{cm}^{2}$ & Despicable \\
$<0.1$ & Moderate \\
$0.1-0.5$ & High \\
0.5 to 1 & Very high \\
$>1$ & \\
\hline \hline
\end{tabular}

The results of the Corrosion Current Density $\left(\mathrm{I}_{\text {corr }}\right)$, were interpreted according to the criteria of the Red Durar Manual (70), see Table VI.

In Fig. 5 present of the results of $\mathrm{I}_{\text {corr }}$ of all specimens' study in a period of 180 days of exposure in a control medium $\left(\mathrm{H}_{2} \mathrm{O}\right)$. The 316 stainless steel has an excellent anti-corrosion behavior with values that are in a negligible area below $0.1 \mu \mathrm{A} / \mathrm{cm}^{2}$. In the case of AISI 1018 steels embedded in a reference concrete and in a $10 \%$ substitution, they show an activation from the beginning of the evaluation period oscillating between a high and moderate level of corrosion. 


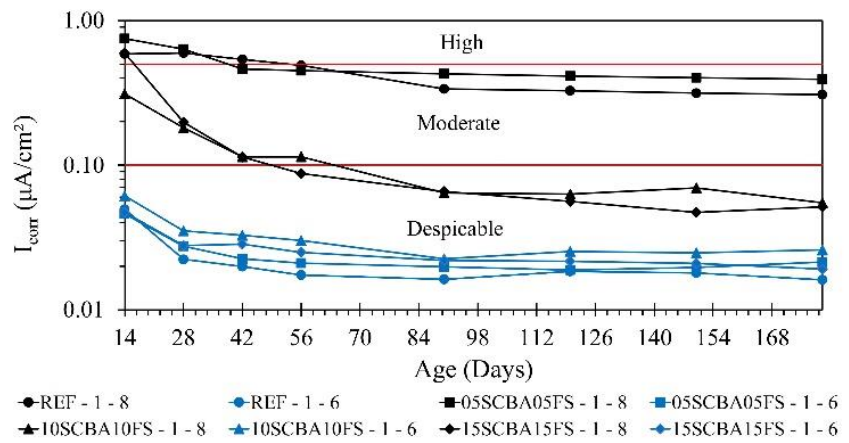

Fig. 5. $\mathrm{I}_{\text {corr }}$ of 316 and 1018 steel in concrete exposed to a control environment $\left(\mathrm{H}_{2} \mathrm{O}\right)$.

The AISI 1018 steels that are found in the mixtures with $20 \%$ and $30 \%$ substitutions (10SCBA10FS and 15SCBA15FS) present an activation in the first 14 days appearing at the high and moderate level of corrosion level and later reach at the age of 63 days a passivity when positioning in a zone of negligible corrosion level. According to the above we can see a benefit to add SCBA and FS in the concrete conventional.

In Fig. 6, the $\mathrm{I}_{\text {corr }}$ results of steels embedded in Green Concrete exposed to a seawater (Aggressive environment) are presented. The specimens with AISI 316 show an excellent behavior when kept in an area of negligible corrosion level, the best behavior is contributed to the $15 \mathrm{SCBA} 15 \mathrm{FS}$ mixture when obtaining values of 0.11 to $0.01 \mu \mathrm{A} / \mathrm{cm}^{2}$.

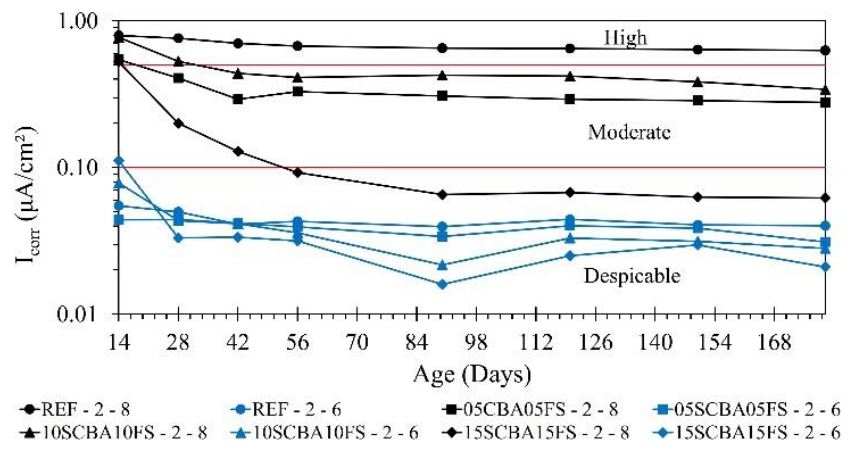

Fig. 6. $\mathrm{I}_{\text {corr }}$ of 316 and 1018 steel in concrete exposed to a marine environment.

The specimens with AISI 1018 presents a greater value of $\mathrm{I}_{\text {corr }}$, from the beginning of the evaluation to the end. The specimen made with the reference concrete $(100 \% \mathrm{CPC})$ is maintained in a zone of high corrosion level all time. However, the $\mathrm{I}_{\text {corr }}$ results of the specimens of the Green Concretes made with 10 and $20 \%$ substitutions of SCBA and FS (5SCBA5FS and 10SCBA10FS) from the day 35 they have a tendency to a zone of moderate corrosion level. The best performance is attributed to the Green Concrete made with a $30 \%$ substitution (15SCBA15FS) present the AISI 1018 steel embedded activation in the first 14 days of exposure, later passing to an area of corrosion level moderate until day 49 and subsequently remained in a zone of negligible corrosion level to obtain 0.92 to $0.06 \mu \mathrm{A} / \mathrm{cm}^{2}$.

\section{CONCLUSIONS}

The specimens with AISI 316 embedded in Green Concrete made with $30 \%$ (15\% of Suggar Cane Bagasse Ash and $15 \%$ of Silica Fume) showed the better behavior or corrosion resistance after the 180 of exposition in Seawater (Aggressive environment), with values of $\mathrm{I}_{\text {corr }}$ below $0.10 \mu \mathrm{A} / \mathrm{cm}^{2}$.

The specimens with AISI 1018 steel embedded in the Green Concrete, made with 30\% (15\% of Suggar Cane Bagasse Ash and $15 \%$ of Silica Fume), presents a very acceptable behavior; with a moderate corrosion level until day 49 , for to present values of $I_{\text {corr }}$ of 0.92 to $0.06 \mu \mathrm{A} / \mathrm{cm}^{2}$ to the end the monitoring due to the denser concrete matrix of Green Concrete.

The best percentage of substitution in Green Concretes was $30 \%$ (15\% of Suggar Cane Bagasse Ash and 15\% of Silica Fume), presenting the best performance against corrosion when using AISI 316 stainless steel when exposed to very aggressive media such as seawater.

The results show that Green Concretes can be used to build Civil Infrastructure in marine environments, presenting great resistance against corrosion by seawater as well as contributing to sustainability due to the use of agro-industrial and industrial waste that the least in Mexico is not used in the proportions and combinations presented in this research.

\section{ACKNOWLEDGMENT}

MA Baltazar-Zamora et al., thank PRODEP for the support granted by the SEP, the Academicians UV-CA-458 "Sustainability and Durability of Materials for Civil Infrastructure" under the Call 2018 for Strengthening Academic Bodies with IDCA 28593. Thanks for the technical support to Brenda Paola Baltazar García.

\section{REFERENCES}

[1] G. Cosoli, A. Mobili, N. Giulietti, P. Chiariotti, G. Pandarese, F. Tittarelli, T. Bellezze, N. Mikanovic, G.M. Revel. Performance of concretes manufactured with newly developed low-clinker cements exposed to water and chlorides: Characterization by means of electrical impedance measurements. Construction and Building Materials. 2020;271:121546.

[2] M.A. Baltazar-Zamora, J.M. Mendoza-Rangel, R. Croche, C. GaonaTiburcio, C. Hernández, L. López, F. Olguín, F. Almeraya-Calderón. Corrosion Behavior of Galvanized Steel Embedded in Concrete Exposed to Soil Type MH Contaminated with Chlorides. Frontiers in Materials. 2019;6:1-12.

[3] C. Pan, X. Li, J. Mao. The effect of a corrosion inhibitor on the rehabilitation of reinforced concrete containing sea sand and seawater. Materials. 2020;13:1480.

[4] G. Santiago-Hurtado et al. Electrochemical Evaluation of a Stainless Steel as Reinforcement in Sustainable Concrete Exposed to Chlorides. International Journal of Electrochemical Science. 2016;11(4):29943006.

[5] M. Ormellese, M. Berra, F. Bolzoni, T. Pastore. Corrosion inhibitors for chlorides induced corrosion in reinforced concrete structures. Cement and Concrete Research. 2006;36(3):536-547.

[6] V. Volpi-León, L.D. López-Léon, J. Hernández-Ávila, M.A. BaltazarZamora, F.J. Olguín-Coca, A.L. López-León. Corrosion study in reinforced concrete made with mine waste as mineral additive. International Journal of Electrochemical Science. 2017;12(1):22-31.

[7] W. Raczkiewicz, A. Wójcicki. Temperature Impact on the Assessment of Reinforcement Corrosion Risk in Concrete by Galvanostatic Pulse Method. Applied Sciences. 2020;10:1089.

[8] M.A. Baltazar-Zamora, S. Márquez-Montero, L. Landa-Ruiz, R. Croche, O. López-Yza. Effect of the type of curing on the corrosion 
behavior of concrete exposed to urban and marine environment. European Journal of Engineering Research and Science. 2020;5(1):9195.

[9] R. E. Melchers, C.Q. Li. Reinforcement corrosion initiation and activation times in concrete structures exposed to severe marine environments. Cement and Concrete Research. 2009;39(11):10681076.

[10] O. Troconis de Rincón et al. Reinforced Concrete Durability in Marine Environments DURACON Project: Long-Term Exposure. Corrosion. $2016 ; 72(6): 824-833$

[11] S.D. Cramer, B.S. Covino, S.J. Bullard, G.R. Holcomb, J.H. Russell, F.J. Nelson, H.M. Laylor, S, M. Soltesz. Corrosion prevention and remediation strategies for reinforced concrete coastal bridge. Cement and Concrete Composites. 2002;24(1):101-117.

[12] L. Landa-Ruiz, H. Ariza-Figueroa, G. Santiago-Hurtado, V. MorenoLanderos, R. López Meraz, R. Villegas-Apaez, S. Márquez-Montero, R. Croche, M.A. Baltazar-Zamora. Evaluation of the Behavior of The Physical and Mechanical Properties of Green Concrete Exposed to Magnesium Sulfate. European Journal of Engineering Research and Science. 2020;5(11):1353-1356.

[13] R.B. Figueira. Electrochemical sensors for monitoring the corrosion conditions of reinforced concrete structures: A review. Applied Sciences. 2017;7:1157.

[14] M.A. Baltazar-Zamora, L. Landa-Ruiz, Y. Rivera, R. Croche. Electrochemical Evaluation of Galvanized Steel and AISI 1018 as Reinforcement in a Soil Type MH. European Journal of Engineering Research and Science. 2020;5(3):259-263.

[15] V. Farhangi, M. Karakouzian. Effect of fiber reinforced polymer tubes filled with recycled materials and concrete on structural capacity of pile foundations. Applied Sciences. 2020;10:1554.

[16] L. Landa-Ruiz et al. Evaluation of the Influence of the Level of Corrosion of the Reinforcing Steel in the Moment-Curvature Diagrams of Rectangular Concrete Columns. European Journal of Engineering and Technology Research. 2021;6(3):139-145.

[17] W. Raczkiewicz. Use of polypropylene fibres to increase the resistance of reinforcement to chloride corrosion in concretes. Science and Engineering of Composite Materials. 2021;28(1):555-567.

[18] A. Landa-Gómez et.al. Corrosion Behavior 304 and 316 Stainless Steel as Reinforcement in Sustainable Concrete Based on Sugar Cane Bagasse Ash Exposed to $\mathrm{Na}_{2} \mathrm{SO}_{4}$. ECS Transactions. 2018;84(1):179188.

[19] W. Raczkiewicz, P.G. Kossakowski. Electrochemical diagnostics of sprayed fiber-reinforced concrete corrosion. Applied Sciences. 2019; 9:3763.

[20] A. Landa-Gómez et.al. Correlation of Compression Resistance and Rupture Module of a Concrete of Ratio w/c $=0.50$ with the Corrosion Potential, Electrical Resistivity and Ultrasonic Pulse Speed. ECS Transactions. 2018;84(1):217-227.

[21] G.P. Millán Ramírez et.al. Deterioration and Protection of Concrete Elements Embedded in Contaminated Soil: A Review. Materials 2021;14:3253.

[22] G. Cosoli, A. Mobili, F. Tittarelli, G.M. Revel, P. Chiariotti. Electrica Resistivity and Electrical Impedance Measurement in Mortar and Concrete Elements: A Systematic Review. Applied Sciences. 2020;10: 9152.

[23] W. Raczkiewicz et.al. Influence of the Type of Cement and the Addition of an Air-Entraining Agent on the Effectiveness of Concrete Cover in the Protection of Reinforcement against Corrosion. Materials. $2021 ; 14: 4657$

[24] M.T. Liang, J.J. Lan. Reliability analysis for the existing reinforced concrete pile corrosion of bridge substructure. Cement and Concrete Research. 2005;35(3):540-550.

[25] L. Landa-Ruiz, S. Márquez-Montero, G. Santiago-Hurtado, V. Moreno-Landeros, J.M. Mendoza-Rangel, and M.A. Baltazar-Zamora. Effect of the Addition of Sugar Cane Bagasse Ash on the Compaction Properties of a Granular Material Type Hydraulic Base. European Journal of Engineering and Technology Research. 2021;6(1):76-79.

[26] O. Ojeda-Farías, J.M. Mendoza-Rangel, M.A. Baltazar-Zamora Influence of sugar cane bagasse ash inclusion on compacting, CBR and unconfined compressive strength of a subgrade granular material Revista ALCONPAT. 2018;8(2):194-208.

[27] H.A.F. Dehwah, M. Maslehuddin, S.A. Austin. Long-term effect of sulfate ions and associated cation type on chloride-induced reinforcement corrosion in Portland cement concretes. Cement and Concrete Composites. 2002;24(1):17-25.

[28] M.A. Baltazar-Zamora et al. Efficiency of Galvanized Steel Embedded in Concrete Previously Contaminated with 2,3 and $4 \%$ of $\mathrm{NaCl}$. International Journal of Electrochemical Science. 2012;7(4):29973007.
[29] S.R. Yeomans. Performance of Black, Galvanized, and Epoxy-Coated Reinforcing Steels in Chloride- Contaminated Concrete. Corrosion. 1994;50(1):72-81.

[30] M.A. Baltazar-Zamora, D.M. Bastidas, G. Santiago-Hurtado, J.M. Mendoza-Rangel, C. Gaona-Tiburcio, J.M. Bastidas, F. AlmerayaCalderón. Effect of Silica Fume and Fly Ash Admixtures on the Corrosion Behavior of AISI 304 Embedded in Concrete Exposed in $3.5 \% \mathrm{NaCl}$ Solution. Materials (Basel). 2019;12(23):1-13.

[31] F. Shaheen, B. Pradhan. Influence of sulfate ion and associated cation type on steel reinforcement corrosion in concrete powder aqueous solution in the presence of chloride ions. Cement and Concrete Research. 2017;91:73-86

[32] M.A. Baltazar-Zamora, A. Landa-Sánchez, L. Landa-Ruiz, H. ArizaFigueroa, P. Gallego-Quintana, A. Ramírez-García, R. Croche, S. Márquez-Montero. Corrosion of AISI 316 Stainless Steel Embedded in Sustainable Concrete made with Sugar Cane Bagasse Ash (SCBA) Exposed to Marine Environment. European Journal of Engineering Research and Science. 2020;5(2):127-131.

[33] G. Roventi, T. Bellezze, G. Giuliani, C. Conti. Corrosion resistance of galvanized steel reinforcements in carbonated concrete: Effect of wetdry cycles in tap water and in chloride solution on the passivating layer Cement and Concrete Research. 2014;65:76-84.

[34] M.A. Baltazar-Zamora, G. Santiago-Hurtado, V.M. Moreno L, R Croche B, M. de la Garza, F. Estupiñan L, P. Zambrano R., C. GaonaTiburcio. Electrochemical Behaviour of Galvanized Steel Embedded in Concrete Exposed to Sand Contaminated with $\mathrm{NaCl}$. International Journal of Electrochemical Science. 2016;11(12):10306-10319.

[35] D. Wang, X. Zhao, Y. Meng, Z. Chen. Durability of concrete containing fly ash and silica fume against combined freezing-thawing and sulfate attack. Construction and Building Materials. 2017;147: 398-406.

[36] M.A. Baltazar-Zamora, G. Santiago-Hurtado, C. Gaona-Tiburcio et al. Evaluation of the corrosion at early age in reinforced concrete exposed to sulfates. International Journal of Electrochemical Science. 2012;7(1):588-600.

[37] V.V. Praveen, D. Ravi. Influence of supplementary cementitious materials on strengthand durability characteristics of concrete. Advanced in Concrete Construction. 2019;7:75-85.

[38] G. Santiago-Hurtado et al. Electrochemical Evaluation of Reinforcement Concrete Exposed to Soil Type SP Contaminated with Sulphates. International Journal of Electrochemical Science. 2016;11(6):4850-4864

[39] G. Burtuujin, D. Son, I. Jang, C. Yi, H. Lee. Corrosion behavior of prerusted rebars in cement mortar exposed to harsh environment. Applied Sciences. 2020;10:8705

[40] A. Landa-Sánchez et al. Corrosion Behavior of Steel-Reinforced Green Concrete Containing Recycled Coarse Aggregate Additions in Sulfate Media. Materials (Basel). 2020;13(19):1-22.

[41] M.L. Berndt. Properties of sustainable concrete containing fly ash, slag and recycled concrete aggregate. Construction and Building Materials. 2009;23(7):2606-2613.

[42] H.A. Ariza-Figueroa et al. Corrosion Behavior of AISI 304 Stainless Steel Reinforcements in SCBA-SF Ternary Ecological Concrete Exposed to $\mathrm{MgSO}_{4}$. Materials (Basel). 2020;13(10):1-16.

[43] P. Xu, L. Jiang, M. Guo, J. Zha, L. Chen, C. Chen, N. Xu. Influence of sulfate salt type on passive film of steel in simulated concrete pore solution. Construction and Building Materials. 2019;223:352-359.

[44] Miguel Angel Baltazar-Zamora, Hilda Ariza-Figueroa, Laura LandaRuiz, and René Croche. Electrochemical Evaluation of AISI 304 SS and Galvanized Steel in Ternary Ecological Concrete based on Sugar Cane Bagasse Ash and Silica Fume (SCBA-SF) exposed to $\mathrm{Na}_{2} \mathrm{SO}_{4}$ European Journal of Engineering Research and Science. 2020;5(3):353-357.

[45] B. Pradhan. Corrosion behavior of steel reinforcement in concrete exposed to composite chloride-sulfate environment. Construction and Building Materials. 2014;72:398-410.

[46] L. Landa-Ruiz et al. Electrochemical Corrosion of Galvanized Steel in Binary Sustainable Concrete Made with Sugar Cane Bagasse Ash (SCBA) and Silica Fume (SF) Exposed to Sulfates. Applied Sciences. 2021;11:2133.

[47] Md. Safiuddin, J.S. West, K.A. Soudki. Hardened properties of selfconsolidating high performance concrete including rice husk ash. Cement and Concrete Composites. 2010;32:708-717

[48] W. Wu, R. Wang, C. Zhu, Q. Meng. The effect of fly ash and silica fume on mechanical properties and durability of coral aggregate concrete. Construction and Building Materials. 2018;185:69-78

[49] H.A. Mohamed. Effect of fly ash and silica fume on compressive strength of self-compacting concrete under different curing conditions. Ain Shams Eng. J. 2011;2:79-86. 
[50] L. Landa-Ruiz et al. Physical, Mechanical and Durability Properties of Ecofriendly Ternary Concrete Made with Sugar Cane Bagasse Ash and Silica Fume. Crystals. 2021;11:1012.

[51] L. Landa-Ruiz et al. Evaluation of the Behavior of the Physical and Mechanical Properties of Green Concrete Exposed to Magnesium Sulfate. Prime Archives in Material Science. 2021;3:1-12.

[52] E. Arif, M.W. Clark, N. Lake. Sugar cane bagasse ash from a highefficiency co-generation boiler as filler in concrete. Construction and Building Materials. 2017;151:692-703.

[53] R.K. Patra, B.B. Mukharjee. Influence of incorporation of granulated blast furnace slag as replacement of fine aggregate on properties of concrete. J. Clean. Prod. 2017;165:468-476.

[54] ACI. Provision of mixtures, normal concrete, heavy and massive ACI 211.1, p. 29. Ed. IMCYC, Mexico (2004).

[55] ASTM C29 / C29M-07-Standard Test Method for Bulk Density ("Unit Weight") and Voids in Aggregate; ASTM International, West Conshohocken, PA, 2007, www.astm.org.

[56] ASTM C127-15-Standard Test Method for Relative Density (Specific Gravity) and Absorption of Coarse Aggregate; ASTM International, West Conshohocken, PA, 2015, www.astm.org.

[57] ASTM C128-15-Standard Test Method for Relative Density (Specific Gravity) and Absorption of Fine Aggregate; ASTM International, West Conshohocken, PA, 2015, www.astm.org.

[58] ASTM C136 / C136M-14-Standard Test Method for Sieve Analysis of Fine and Coarse Aggregates; ASTM International, West Conshohocken, PA, 2014, www.astm.org.

[59] NMX-C-156-ONNCCE-2010: Determinación del revenimiento en el concreto fresco. ONNCCE S.C., México, (2010).

[60] ASTM C 1064/C1064M - 08 Standard, (2008). Standard Test Method for Temperature of Freshly Mixed Hydraulic-Cement Concrete. ASTM International, West Conshohocken, PA, 2008, www.astm.org.

[61] NMX-C-162-ONNCCE-2014: Determinación de la masa unitaria cálculo del rendimiento y contenido de aire del concreto fresco por el método gravimétrico., ONNCCE S.C., México, (2014).

[62] NMX-C-083-ONNCCE-2014: Determinación de la resistencia a la compresión de especímenes - Método de prueba, ONNCCE S.C., México, (2014).

[63] G. Santiago-Hurtado, M.A. Baltazar-Zamora, A. Galindo D, J.A Cabral M, F.H. Estupiñán L., P. Zambrano Robledo, C. GaonaTiburcio. Anticorrosive Efficiency of Primer Applied in Carbon Steel AISI 1018 as Reinforcement in a Soil Type MH. International Journal of Electrochemical Science. 2013;8(6):8490-8501.

[64] ASTM G 59-97 (2014) - Standard Test Method for Conducting Potentiodynamic Polarization Resistance Measurements, ASTM International, West Conshohocken, PA, 2014, www.astm.org.

[65] M. Criado, D.M. Bastidas, S. Fajardo, A. Fernández-Jiménez, J.M. Bastidas. Corrosion behaviour of a new low-nickel stainless steel embedded in activated fly ash mortars. Cement and Concrete Composites. 2011;33(6):644-652.

[66] S. Feliu, J. A. González, and C. Andrade, Techniques to Assess the Corrosion Activity of Steel Reinforced Concrete Structures, ASTM STP 1276. ASTM, 1996.

[67] ASTM C 876-15, Standard Test Method for Corrosion potentials of uncoated reinforcing steel in concrete, ASTM (2015).

[68] H.W. Song, V. Saraswathy. Corrosion Monitoring of Reinforced Concrete Structures - A Review. International Journal of Electrochemical Science. 2007;2(1):1-28.

[69] O. Troconis De Rincón et al. Manual de Inspección, Evaluación y Diagnóstico de Corrosión en Estructuras de Hormigón Armado, p. 134. Red DURAR. CYTED. Venezuela (1997). 